\title{
JARGONS USED BY MALE BALINESE DANCER AT SANGGAR SENI MANIK UTTARA SINGARAJA
}

Yadnya, I N. N

English Education Department, Ganesha University of Education e-mail: nityanandayadnya22@gmail.com

Ramendra, D. P. English Education Department, Ganesha University of Education e-mail: putu.ramendra@undiksha.ac.id

Utami, I.A.M.I

English Education Department, Ganesha University of Education e-mail: istriutami@undikdha.ac.id

\begin{abstract}
This study aimed at analyzing forms, meaning, and function of jargons used by male Balinese dancer at Sanggar Seni Manik Uttara Singaraja. This study was conducted in descriptive qualitative method. the subject of this study were 2 dancers of Traditional Balinese Dance especially male dancer in Sanggar Seni Manik Uttara Singaraja. In this study, the methods of data collection were observation and interview. The result of this study represents there are 22 jargons used by male Balinese dancer at Sanggar Seni Manik Uttara Singaraja in which jargons were classified and investigated based on word formation processes and word class. There are 5 affixations, 5 nouns, 2 verbs, 7 compounding, 3 reduplications. The meaning of jargons was analyzed based on the context of male Balinese dancers' conversation, picture, and interview. Additionally, this study denotes there are three function of jargons used by male Balinese dancer, to make communication effectively, to show the identity of the dancer and the last is to build the solidarity among Balinese dancer.
\end{abstract}

Keywords: sociolinguistics, language variety, jargon, male Balinese dancer

\section{INTRODUCTION}

Language is portrayed as a powerful tool to communication (Novianti, 2017). Communication is important in which people use language in their communication. Language is used to express feelings, ideas and information towards others, which is used everywhere in our daily life (Seken, 1992). He also states that language is a system of arbitrary vocal symbol by means of which members of a social group interact and cooperate for communication. Communication is really important for our daily life, language is a system of communication between individual and social phenomenon (Hickey, Language and Society, 2012). Language can be use by people based on their context and also language can convey the speaker's feeling and information to the hearer in communication (Liaw, Dani, \& Johari, 2013). 
Talk about language as tool of communication there have deeply relation with linguistics. Linguistics is a scientific study of language and the language structure. Linguistics is a study of language that also learn about the analysis language form, language meaning and also language in context (Marousek, 2015). In linguistics we are going to learn about so many aspect of human language including sounds (phonetics and phonetics, phonology), words (morphology), sentences (syntax), and meaning (semantics). Linguistics also learn about the relationship between language and social phenomenon that's call sociolinguistics (Hickey, Language and Society, n.d.). Sociolinguistics is concerned with investigating the relationships between language and society with the goal being a better understanding of the structure of language and of how languages function in communication (Wardhaugh, 2006). Moreover, society is a group of people associated with culture, religion, politics, science, profession and other purpose. So language will be different from one people with the another people in different society. In order to recognize the social function of language and to know the ways in which social meaning are expressed, there is a term jargon as the variety of language (Wardhaugh, 2006).

Language variety is an important part of sociolinguistics to know how the social factors can affect the language itself. Language variety is any general term of form of a language and language expression (Nordquist, Definition and Examples of Language Varieties , 2018).

Jargon belongs to language variety in sociolinguistics. Theoretically of jargon means the language which specialized term used in profession in which it has unfamiliar terms (Wright, 2010). Jargon is a language which is particularly used by people in certain profession, group and trade (Marousek, 2015). He also states that jargon is a language which describes and defines the world in which its users lives and work. Commonly it is only understand by the experts of the profession itself in order to make their time efficient and easier to make a communication (Wright, 2010). According to Liaw, Dani, \& Johari (2013) state that jargon is particularly term that used in profession, trade, and group in which there are not understood outside by the society. In addition, jargon is special vocabulary which difficult to transfer to the person who don't involve too long in a company or organizations (Yazdanifard \& Patoko, 2014). Jargon refers to specialized language in which the language is usually used in specific context.

Jargon not only used in profession but also used in arts and culture for example Balinese Dance in Bali. Traditional Balinese dance also used jargons in the communication. The jargon used to make communication in the group of Balinese dance efficiently. Bali has so many culture and art that excited to be known. Culture is a social system that use in society (Baecker, 2015). In sociolinguistics theory, culture also give affect for the society language or society communication. Balinese culture also has jargon that can be used in their daily live. Since Bali Island famous with art and culture there are so many tourists come to the Bali island to see and learn about the art and culture itself. It's mean the tourist also wants to learn or know about the language that used in the art and culture itself. Balinese dance have big energy to attractiveness the tourist come to Bali and try to learn about the Balinese dance. Balinese dance is famous dance in the world that have so many meaning and so many attractions. UNESCO is a world organization that walk in Educational, Scientific and Cultural also note Balinese Dance as the world heritage. According to UNESCO there are Nine traditional Balinese dances have been recognized as part of the world's intangible cultural heritage following a UNESCO session in Namibia, there are: Barong Ket, Joged Bumbung, Legong 
Keraton, Topeng Sidhakarya, Baris Upacara, Sanghyang Dedari and Rejang dances, as well as the Wayang Wong and Gambuh dance dramas (Sugiartha, 2018). It's the fact the Balinese dance is an important and famous art and culture.

An interesting phenomenon has been faced by the researcher in Ganesha University of Education (UNDIKSHA) Singaraja when teach and introduce traditional Balinese Dance to the student of BIPA (Bahasa Indonesia untuk Penutur Asing) student program. The dancer actually used the technical language in their communication and their practice which meant that the researcher and BIPA student who did not belong this organization was confused and difficult to understand the meaning of their communication especially the jargon of traditional Balinese dance. It's make the BIPA (Bahasa Indonesia untuk Penutur Asing) student program difficult to follow the instructors because they didn't know about the jargons meaning. Balinese dance also has the jargon that not all the people know about the meaning of that jargon. Actually the jargon of traditional Balinese dance only understood by the expert, the instructors, or the dancer only. The characteristic of jargon is its ability to be understood only by people who have a particular knowledge of field where the jargon is usually used (Marousek, 2015). It's mean the people who unfamiliar with the field will be confused to understand the meaning of that jargon.

Based on that phenomenon the researcher wants to conduct the research about traditional Balinese Dance jargons that used by in Ganesha University of Education Singaraja when they teach traditional Balinese Dance to the student of BIPA (Bahasa Indonesia untuk Penutur Asing) program at Sanggar Seni Manik

Uttara Singaraja as the actively organization that mastering and focus in Balinese culture and art especially Balinese dance. The aim of this study is to analyzing the forms and meanings of jargon use and interpreting the function of jargons use of male traditional Balinese dance.

This research was conducted to know the meaning of the jargons, the form of the jargons and the function of the jargons based on the contect of male balinese dancer at sanggar seni manik uttara singaraja.

\section{METHODS}

Descriptive qualitative method was used as a design to investigate the study in this research. In this study, the researcher focused to analyzed the form, meaning, and function of jargons that used by Traditional Male Balinese Dancer in Sanggar Seni Manik Uttara the one art organization in Singaraja. The data taken by doing the observation of every event happened in the practice room during the practice process and every event that happened outside the practice room. Moreover, researcher was conducted the interview to the male Balinese dancer in Sanggar Seni Manik Uttara Singaraja.

In this study the researcher chooses some subjects. There are two subject in this study, the subject of this study is 2 dancers of Traditional Balinese Dance especially male dancer in Sanggar Seni Manik Uttara Singaraja. Those 2 dancers will be male dancer that got productive courses that related to the Balinese Dance theory and also actively practice in Sanggar Seni Manik Uttara Singaraja. The dancer that as a subject in this study also already directly have experiences as Balinese dancer such as joining the Balinese dance event, and also have experiences as the Balinese dance instructor. In this study the researcher was collect the data by conducted the observation and interview. 
The researcher was asking the subject about some information about the Balinese dance jargons especially the jargons that used in male Balinese dance. And also the researcher was observing the subject during their practiced in Sanggar Seni Manik Uttara Singaraja. The researcher conducted the observation and interview in the practice room during the practiced process and the outside of the practiced room.

The object of this study is the jargons that used by male Traditional Balinese Dance. This study was conducted because of phenomenon of jargons Balinese Dance as an interesting phenomenon. In this research, the researcher used video recorder to record the activity in the practice Balinese dance at Sanggar Seni Manik Uttara Siangaja. From the video the researcher was known the jargon and also the movement of the jargon. It made the researcher easier to get the data and easier to transfer the data. From the video, the researcher was capture the movement in different jargons.

Researcher also used interview guide to collected the information related to this current research. Interview guide e made by the researcher to interview the dancers to colected more information related to the jargons that use in male Balinese dance and confirm results of questionnaire from the dancers. It was also has some questions which used to interview the dancers.

In this research, data was collected through observation and interview. Data for this current research was collected through four steps. The first step, researcher prepared the instruments that used in this current research, such as digital recorder, notebook, video recorder and interview guide. The second step, researcher was recorded the dancer's activity in practice the Traditional Balinese. The recorder has a purpose to observe the jargons that use during their practice. The third step, the researcher was interview the dancer by following interview guide and the researcher recorded by using digital recorder. During the interview, the researcher also taken a note in the notebook. It has a purpose to investigate the jargons that used in male Balinese dance. The last steps is, data obtained from recording, and also interview was analyzed used Qualitative Data Analysis and presented as result of this current research.

Data validity is needed in conducting every research. It will prove that data obtained by the researcher is valid and reliable. In order to prove data obtained is valid and reliable, trustworthiness is used to help to prove credibility of the data. To check trustworthiness of the data, triangulation will be used to avoid bias in the results of this current study. Triangulation will help data in this research become valid and reliable. It will have different method to review the data collected in this current research and it will make the results of this current research more accurate and valid in qualitative research design (Hoyo \& Allen, 2006). Denzin and Norman (1973) explain that, there are four types of triangulation, namely: source triangulation, investigator triangulation, theory triangulation, and methodological triangulation.

\section{FINDINGS AND DISCUSSION}

The researcher found the jargon used by the male Balinese dancer at Sanggar Seni Manik Uttara Singaraja. The researcher conducted the observation and interview in order to got the jargons that they used in the Balinese dance especially male Balinese dancer at Sanggar Seni Manik Uttara Singaraja. There were 22 jargons used by male Balinese dancer at sanggar Seni manik Uttara Singaraja. The jargons as the result of this study had been classified and investigated based on the jargons in the part of human body and also based on the word formation processes and word class. If the jargons classified by the position in the parts of body there are 7 jargons is located in the head, 8 
is located in upper body parts such as hands, shoulder, fingers, back and waist, and also 7 is located in lower body parts such as legs, thighs, ankles, soles of feet and toes. If the jargons had classified by the word processes and word class there are 5 affixations, 5 nouns, 2 verbs, 7 compounding, 3 reduplications. Nyeledet is come from word seledet. The word Nyeledet is derived from the root seledet. Nyeledet is movement in the eyes. The movement of nyeledet is the way of glancing at the right side or left corner of the eye and the end of the movement the position of the eyeball is back to the middle position. This movement often used in every kind of male Balinese dance such as Baris Dance, Gopala Dance and etc.

The next jargon is Ngelier. The word Ngelier is derived from root selier. Ngelier is the come from Balinese language. Ngelier is formed by adding prefix nge- before the root selier. Ngelier is the eye movement which is emphasis on half-closing to one of the eyes. Usually, Ngelier can follow by and it will be followed by head rotating to the right or left which correspond with the eyes that closed.

The next one is Nyerenggu. This movement usually used in Baris Gede dance. The word Nerenggu is derived from root serenggu. Nyerenggu is the come from Balinese language. Nyerenggu is a part of head movement especially in eye brow. Nyerenggu is the movement of narrowing the eyebrows.

The next jargon is Nyegut. The word Nyegut is derived from root segut. Nyegut is formed by adding prefix nye- before the root segut. Nyegut is the combination movement of neck and chin. The movement which similar to nodding. And after that, the eyes look down followed by the head. This movement actually used in Baris Gede and Gopala dance.

Nyeregseg is the quickly movement. Nyeregseg is a movement in which the feet on tiptoe and shifted to the side through moving the feet quickly. Nyeregseg is derived from root seregseg.

The next jargon is Nelik. Nelik is come from Balinese language that have same meaning with glaring in English. Nelik is a verb theat come form noun delik. Nelik is the jargon to indicate the movement in the eyes. Nelik is movement of lifting eyebrows and eyes which focuses on one point. The next jargon is Kipek. Kipek is the head movement. The movement of Kipek is the dancer can turn their head right or left around 45 degrees. This movement commonly used in Baris Gede dance.

The next jargon is Ngontag. Ngontag is the breaking movement of head into right or to left. It moves to the right and to the left slowly. The next jargon is Jeriring. Jeriring is movement of finger. Jeriring is a part of hands movement the focus on finger. Jeriring is the finger movement through shaking each finger and at the same time. That is a movement that vibrates the hands so that the dancer's fingers look alive. Tanjak is classified as noun. Tanjak is the position to indicate the outhority gesture. The position of tanjak is the tiptoe position of the right or left foot during agem and the position of the tiptoe is parallel to the other toe.

The next jargon is Ngunda. Ngunda is a part of the male banlinese dance movement. Ngunda is commonly use in Baris dance. Ngunda a noun. Ngunda is the ups and downs movement of male Balinese dance.

The next jargon is Malpal. Malpal is classified as verb. Malpal is The foot movement where the foot position is opened as width as the shoulder, then the foot is rotated 90 degrees. Malpal have 5 steps, the first step is the legs are parallel and low position, the second step is the left leg is lifted until the heel touches the back of the knee, next the foot returns to its original position, in the next step the opposite leg is lifted to touch the 
back of the knee. And the last the position of the foot is back to normal and repeated onwards. Ngupak lantang is classified as compounding. Ngupak lantang is the position of male Balinese dance that commonly use in Baris Gede dance, Baris Tunggal dance, Jauk dance and etc. Ngupak Lantang is the hands movement that The final positions of the left hand forms carpenter square, then the right hand is straight and looks for a 45degree angle (right agem). Those movements are vice with the opposite direction for left agem.

Agem is the basic position of Balinese Dance. Agem in male dance is different from female dance. Agem position in male dance are indicate a firmness. In Balinese dance there are types of 2 agem, the first one is agem kanan and the second is agem kiri. Agem Kanan is The movement of raising the right hand which is parallel to the right eye. Meanwhile, the left hand is parallel to the chest. The position of hands is opened and thumbs are folded.

Agem kiri is classified as compounding. The position of agem kiri is raising the left hand which is parallel to the left eye. Meanwhile, the right hand parallel to chest. The position of hands is opened and thumbs are folded.

The next jargon is Tapak Sirang Pada. Tapak sirang pada is classified as compounding. Tapak sirang pada in male dance is different with female dance. Tapak Sirang Pada is position of foot. For men The foot position which is equally hoarse or facing outward at a 90 degrees' angle.

The next jargon is Miles Kanan. Miles kanan is classified as compounding. Miles is come from Balinese langanguage. Miles kanan is a part of foot movement. Miles kanan is the position of the right foot is tilted and the heel of the right foot is rotated 90 degrees from the incline.

The next jargon is Miles Kiri. Miles is come from Balinese langanguage. Miles kiri is a part of foot movement. Miles kiri is classified as compounding. Miles kiri is The position of the left foot is tilted and the heel of the left foot is rotated 90 degrees from the incline.

The next jargon is Angkat Pala. Angkat Pala come from two words "Angkat" and "Pala". "Angkat" is mean lift or raising and "Pala" is mean shoulders. Angkat Pala is the way of raising shoulders to cover the right and left side of the neck. The shoulders are lifted to touch the jawbone. Angkat pala is classified as compounding. Ukel- ukel is one of hands movements. Ukel ukel is the movement of turning hands from outside to inside. Ukel ukel is come from word "ngukel" in Balinese language. Ukel ukel is classified as reduplication. Ukel ukel have 5 steps that focus in hands and finger movement.

The next jargon is Ulap- ulap. Ulap- ulap is classified as reduplication. Ulapulap is the part of hands movement. The movement is like waving to call a person. For right agem, the position of the ulap-ulap is leaning to the left. The wrists of the hands are up to above the eyes, then the left hand is in the head above the eyebrows. After that, glancing the eye to the upper right corner. Those movements are vice versa with the opposite direction for the left agem.

Sleag- sleog is the body movement which is leaning to the right side and left side. The main movement of sleag- sleog is Half squat position with view angle 45 degrees to the right and rather leaning forward.

Jargons that used by male Balinese dancer also have some function for the dancer itself. In this research, the researcher found three function the first one to make communication effectively. The dancer used the jargon to made the communication 
between the dancer easier to use and easier to understanding. Especialy if the dancer can make a new dance movement it can make the dancer easy to understand the movement that they can used. In another way effective in here also means the dancer can use the jargon to avoid the miss communication among the dancer. This function inline with Patoko \& Yazdanifard (2014), they state Jargon aims at speeding up the communication, helping someone's to think, and can make simplifying the communication between the user. This function also related with theory by Liaw, Dani, \& Johari (2013) they state that jargons is an efficient method that used to communicate with each other. It means jargon is a good method to make an effective communication in a group or proffesion.

The second is to show the identity of the dancer. By using that jargons the dancer can have their own characteristic as a dancer. it means, by using their own vocabulary they can fell have a special characteristic because the language or the vocabulary that they used only understood in their group or proffesion. By have characteristic the dancer can be attract someone to learn also about the Balinese dancer. it's a good thing for Balinese culture. The characteristics of the dance performed will be clearer with the jargons used by the dancer it'self. And the last is to built the solidarity among Balinese dancer. The dancer belive that a good communication can make a good solidarity. Solidarity in a dance is important because if the dancer have a good solidarity they can easier to dance together and can make a good movement together. If in the dance group have less solidarity it can make the group broke and hardest or make a good dance. So because of that the solidarity also affect the dancer show in the stage. In another way, solidarity also come cause the communication between the dancer effective and the dancer easy to understand what the another dance wants and mean. Inline, according to Liaw, Dani, \& Johari (2013) state that jargons are an efficient method that used to communicate with each other, it means jargons is a good way to make a group keep solid because they have a good and easy communication.

\section{CONCLUSIONS}

In conclusion, this study was conducted in Sanggar Seni Manik Uttara Singaraja, Buleleng, Bali. This study has answered three statements of problem which are forms, meaning, and function of jargons used by male Balinese dance at Sangar Seni Manik Uttara Singaraja inside and outside the practice room. Descriptive qualitative method was used as a design to investigate the study in this research. The data taken by doing the observation of every event happened in the practice room during the practice process and every event that happened outside the practice room. Moreover, researcher was conducted the interview to the male Balinese dancer in Sanggar Seni Manik Uttara Singaraja. The result of this study represents there are 22 jargons used by male Balinese dancer at Sanggar Seni Manik Uttara Singaraja in which jargons were classified and investigated based on word formation processes and word class. there are 5 affixations, 5 nouns, 2 verbs, 7 compounding, 3 reduplications. The researcher discovered jargons and meaning by doing the interview and observation. Moreover, jargons used by male Balinese dancer have three functions, the first one to make communication effectively, the second is to show the identity of the dancer and the last is to build the solidarity between the dancer.

Based on the findings, there are three suggestions delivered by the researcher which are explained as follows: The result of this study was expected to be important for traditional Balinese dance instructor and ESP teacher. This study can help the 
teacher and instructor to deliver the meaning of the jargon so they can easier to teach the traditional Balinese dance to all the participants. Since ESP deals with specific vocation or interest of various fields of society in which they can use the result of this study as learning resource containing description and analysis of forms, meanings, and function of jargons for teaching nursing students. From this study the teacher and instructor can have a vocabulary and the meaning to teach the traditional Balinese dance especially male dance.

\section{REFERENCES}

Baecker, D. (2015). The Meaning Of Culture. Thesis Eleven, 37-51.

Denzin, \& Norman, K. (1973). The Research Act: A Theoretical Introduction To Sociological Methods. New Jersey: Transaction Publishers.

Hickey, R. (2012). Language And Society. 2-37.

Hickey, R. (N.D.). Language And Society. Retrieved From Www.Uni-Due.De: Https://Www.Uni- Due.De/ELE/Languageandsociety.Pdf

Hoyo, M., \& Allen, D. (2006). The Use Of Triangulation Methods In Qualitative Educational Research. Journal Of College Science Teaching, 42-47.

Liaw, J., Dani, N., \& Johari, A. (2013). Language Usage Of Jargon And Slang In Strategic Studies. Australian Journal Of Basic And Applied Sciences, 661-666.

Marousek, I. (2015). Analysis Of Hotel Jargon And Slang. Brno: Masaryk University Brno.

Nordquist, R. (2018, July 22). Definition And Examples Of Language Varieties . Retrieved From

Www.Thoughtco.Com: Https://Www.Thoughtco.Com/Langua ge-VarietySociolinguistics-1691100

Novianti, D. (2017). Word Formation Analysis Of English Slang Language On Deadpool Movie. Jakarta: State Islamic University Syarif Hidayatullah.

Patoko, N., \& Yazdanifard, R. (2014). The Impact Of Using Many Jargon Words, While Communicating With The Organization Employees. American Journal Of Industrial And Business Management, 567-572.

Sugiartha, I. (2018). Relation Of Dance And Music To Balinese Hinduism. SPAFA Journal, 1-17.

Wardhaugh, R. (2006). An Introduction To Sociolinguistics. Library Of Congress Cataloging-In-Publication Data, 1-426.

Wright, N. (2010, January 10). Plainlanguage.Gov. Retrieved January 20, 2019, From An Official Website Of The United States Government: Https://Www.Plainlanguage.Gov/Reso urces/Articles/Keep-It-Jargon-Free/

Yazdanifard, R., \& Patoko, N. (2014). The Impact Of Using Many Jargon Words, While Communicating With The Organization Employee. American Journal Of Industrial And Business Management, 567-572. 